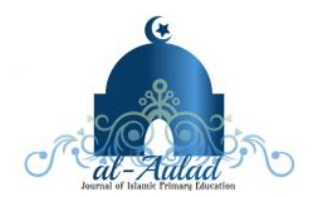

\title{
PENERAPAN TEKNIK AKROSTIK UNTUK MENINGKATKAN KETERAMPILAN MENULIS PUISI SISWA MADRASAH IBTIDAIYAH
}

\author{
Ina Diana ${ }^{1}$, Nasihudin ${ }^{2}$ \\ ${ }^{1}$ Sekolah Dasar Islam Bina Nusantara, Kota Bandung, Jawa Barat, Indonesia \\ ${ }^{2} J u r u s a n$ Pendidikan Guru Madrasah Ibtidaiyah, UIN Sunan Gunung Djati, Bandung, Indonesia \\ inadiana12@yahoo.com
}

Naskah diterima: tanggal 30 Agustus 2018, direvisi: tanggal 11 September 2018, diterbitkan: tanggal 31 Oktober 2018

\begin{abstract}
The purpose of this study was to determine students' poetry writing skills before the application of acrostic techniques, the process of applying acrostic techniques in each cycles, and the increase produced after applying the acrostic technique. The research method used is Classroom Action Research (CAR), consisting of planning, implementing, observing, and reflecting. Based on data analysis, it was concluded that 1) the students' poetry writing skills before applying the acrostic technique obtained an average score of 46.87. 2) The application of acrostic techniques goes well according to the stages. The activity of teachers and students has increased dramatically, in the first cycle the teacher's activity gained a percentage of $64.15 \%$, in the second cycle teacher activity increased to $89.1 \%$. Student learning activities in the first cycle reached $61.65 \%$, in cycle II it increased by $87.5 \%$. 3) Students' poetry writing skills after applying acrostic techniques have increased. In the first cycle, the average score of students was 69.45, and the percentage of learning completeness was $51.75 \%$. In cycle II the average value of students skill increased sharply to 89.37 , and the percentage was $91 \%$. Thus, the CAR carried out has been completed with the expected goal of improving poetry writing skills in Indonesian Language Subjects.
\end{abstract}

Keywords: Acrostic techniques, poetry, writing skill, Indonesian language

\begin{abstract}
ABSTRAK
Tujuan penelitian ini untuk mengetahui keterampilan menulis puisi siswa sebelum diterapkannya teknik akrostik, proses penerapan teknik akrostik pada setiap siklus, dan peningkatan yang dihasilkan setelah diterapkan teknik akrostik. Metode penelitian yang digunakan ialah Penelitian Tindakan Kelas yang terdiri dari perencanaan, pelakasanaan, pengamatan, dan refleksi. Berdasarkan analisis data, diperoleh simpulan bahwa 1) Keterampilan menulis puisi siswa sebelum diterapkan teknik akrostik memperoleh nilai rata-rata 46,87. 2) Penerapan teknik akrostik berjalan baik sesuai dengan tahapannya. Aktivitas guru dan siswa mengalami peningkatan, pada siklus I aktivitas guru memperoleh persentase sebanyak $64,15 \%$, pada siklus II aktivitas guru meningkat menjadi $89,1 \%$. Aktivitas belajar siswa pada siklus I mencapai $61,65 \%$, pada siklus II naik sebsear $87,5 \%$. 3) Keterampilan menulis puisi siswa setelah diterapkan teknik akrostik mengalami peningkatan. Pada siklus I perolehan nilai rata-rata siswa 69,45, dan persentase ketuntasan belajar sebesar 51,75\%. Pada siklus II nilai rata-rata siswa meningkat sebesar 89,37 dan persentase sebesar $91 \%$. Dengan demikian, Penelitian Tindakan Kelas yang dilaksanakan telah selesai dengan tujuan yang diharapkan yakni dapat meningkatkan keterampilan menulis puisi pada Mata Pelajaran Bahasa Indonesia.
\end{abstract}

Kata Kunci: keterampilan menulis, puisi, teknik Akrostik, bahasa Indonesia

\section{PENDAHULUAN}

Pendidikan ialah usaha yang diberikan secara sengaja melalui pengajaran, bimbingan dan latihan (Aisyiyah, 2013, hal. 4). Pendidikan erat kaitannya dengan belajar dimana belajar merupakan suatu proses yang dialami oleh seseorang melalui kegiatan yang dilakukan untuk mencapai tujuan tertentu, sehingga memungkinkan terjadinya perubahan pada sikap, pengetahuan, keterampilan, serta perubahan pada kebiasaan, pengalaman, minat, dan 
penyesuaian dirinya. Pada pembelajaran tematik, ialah program pembelajaran yang sbertolak dari dari satu tema tertentu, kemudian dielaborasi dari berbagai aspek prespektif mata pelajaran yang diajarkan di sekolah. Pembelajaran tematik dibuat untuk meningkatkan hasi belajar secara optimal dan maksimal dengan mengangkat pengalaman peserta didik sebagai sumber pengetahuan (Kadir, 2014, hal. 1-7).

Pendidikan erat kaitannya dengan pembelajara dimana dalam pembelajaran terkandung metode dan teknik untuk penyampaian materi yang dilakukan guru kepada siswa agar dapat diserap dan dipraktekan di dunia nyata. Pembelajaran yang dilaksanakan di sekolah tidak semata-mata hanya untuk menyampaikan materi ajar, tetapi harus mengetahui tujuan dan makna dari pembelajaran tersebut, dengan melakukan pembatasan pada penyampaian materi bahan ajar maka pembelajaran dapat disampaikan dengan terstruktur dan efisien. Pembatasan materi ajar tersebut dapat diadopsi dari kurikulum yang berisi tujuan, isi, bahan pelajaran, dan teknik pembelajaran yang akan digunakan sebagai pedoman untuk penyelenggaraan kegiatan pembelajaran untuk mencapai tujuan pendidikan. Menurut H.J. Gino pembelajaran ialah usaha sadar dan terencana oleh guru agar membuat siswa belajar untuk mengaktifkan faktor intern dan ekstern pada kegiatan belajar mengajar (Rukiati K., 2014, hal. 59)

Pada kehidupan sehari-hari bahasa merupakan alat komunikasi yang selalu dipergunakan untuk menyampaikan pesan kepada seseorang baik secara verbal maupun non verbal. Pada praktiknya, seseorang kesulitan dalam mengutarakan dalam bahasa verbal, untuk dalat menyampaikan bahasa tersebut dapat dilakukan lewat menulis. Mengapa menulis bisa dikatakan alat sebagai komunikasi? Menulis merupakan aktivitas bentuk kemampuan dalam berbahasa yang bersifat aktif produktif.pada penggunaan bahasa tertulis penulis dapat lebih memiliki banyak kesempatan dalam mempersiapkan diri untuk menyampaikan perasaan, diksi, maupun frasa yang akan diungkapkan sehingga, tulisan tersebut dapat dipahami oleh para pembaca (Dadang, 2014, hal. 248). Dalam hal penyampian makna dalam tulisan, tentulah dibutuhkan keterampilan berbahasa tulis yang baik. Agar makna dari pesan tulisan tersebut dapat disampikan dengan baik kepada pembacanya.

Berdasarkan hasil studi pendahuluan di kelas IV B MIN Margasari (MIN 02 Kota Bandung) terdapat permasasalahan terkait dengan keterampilan menulis siswa diantaranya, siswa yang belum bisa membuat karya tulis dengan baik. Permasalahan ini terlihat dari hasil karya tulis siswa seperti, ketika siswa diminta menuangkan ide dalam menulis kesimpulan dari suatu materi pembelajaran maupun menuliskan kembali isi cerita dengan menggunakan bahasa sendiri sebagian besar siswa hanya meringkas dari buku paket yang tersedia, ataupun menulis kembali apa yang diucapkan oleh guru. Permasalahan selanjutnya ialah siswa kesulitan saat menggunakan huruf kapital pada setiap kata yang berhubungan dengan nama orang, bulan, dan tempat karena siswa kerap kali menggunakan huruf kecil pada bagian kata yang berhubungan dengan nama-nama tersebut, bahkan terdapat beberapa siswa yang terbiasa menggunakan huruf kapital di tengah kalimat yang seharusnya tidak menggunakan huruf kapital.

Adapun penelitian relevan yang menjadi acuan saya yaitu: penelitian Nelvin dengan mengambil judul "Penerapan Teknik Akrostik Melalui Aktivitas Terbimbing Untuk Meningkatkan Kemampuan Menulis Puisi Siswa Kelas V SDN Doda”. Hasil tes penilaian siklus I, menunjukan presentase rata-rata kemampuan menulis puisi secara individu adalah $59 \%$, sedangkan ketuntasan klasikal baru mencapai $65 \%$. Hasil nilai rata-rata yang diperoleh pada siklus II meningkat, berdasarkan analisis penilaian ketuntasan individu telah menunjukkan $82,25 \%$ dan ketuntasan klasikal telah mencapai $90 \%$ artinya sudah melampaui kriteria ketuntasan minimal yang dipersyaratkan. Berdasarkan dari hasil penelitian tersebut, 
maka penelitian ini akan membahas mengenai penerapan Teknik Akrostik pada pembelajaran Tema Cita-citaku Sub Tema Aku dan Cita-citaku pada materi puisi untuk meningkatkan keterampilan menulis siswa. Penelitian ini menggunakan metode Penelitian Tindakan Kelas (PTK) dengan penelitian yang berjudul "Penerapan Teknik Akrostik Untuk Meningkatkan Keterampilan Menulis Puisi Pada Tema Cita-citaku Sub Tema Aku dan Citacitaku."

Keterampilan menulis ini merupakan usaha seseorang untuk mengungkapkan pikiran dan perasaan yang terdapat pada diri melalui bahasa tulis. Keterampilan menulis merupakan keterampilan dengan tigkat kesulitan paling tinggi dibandingkan dengan tiga keterampilan (menyimak, berbicara, membaca) lainnya (Suhendar, 2008, hal. 248\&291). Kriteria penulisan puisi dapat diukur dari kemampuan siswa dalam membangun harmoni atau keselarasan pada unsur-unsur puisi, hal ini dapat dilihat dari ketepatan dalam menyusun citraan, diksi, majas, rima ritma, majas, dan tipografi. Dari beberapa kriteria tersebut, maka peneliti mengambil beberapa poin sebagai dasar indikator dari keterampilan menulis puisi. Adapun poin yang diambil sebagai kriteria keterampilan menulis puisi yaitu: 1) Diksi/pilihan kata, 2) Tema, 3) Gaya bahasa, 4) Rima (Abidin, Pembelajaran Bahasa Berasis Pendidikan Karakter, 2013, hal. 289).

Teknik akrostik merupakan salah satu teknik pembelajaran yang dapat diaplikasikan pada pembelajaran menulis. Pada dasarnya, akrostik berasal dari kata Perancis acrostiche dan Yunani akrostichis yang artinya ialah, sebuah sajak yang menempati huruf awal pada setiap barisnya, menyusun sebuah atau beberapa kata (Nur, 2010). Kata akrostik sendiri ialah puisi yang huruf awal pada setiap barisnya membentuk sebuah kata ketika dibaca secara vertikal (Magee, 2008). Sedangkan menurut Rose Colin (Taoziri, 2013) mengenukakan bahwa akrostik merupakan sajak atau susunan kata-kata yang seluruh huruf awal atau akhir pada setiap baris-barisnya merupakan sebuah kata/nama diri yang digunakan untuk mengingat hal lain. Penerapan teknik akrostik dalam pembelajaran menulis puisi dapat dilakukan dengan beberapa tahap sebagai bertikut: a) Menentukan judul puisi, b) Mengurutkan judul puisi secara vertikal, c) Menulis diksi ke dalam huruf-huruf yang telah disusun secara vertikal, d) Tahap penyuntingan (Salam, 2009). Adapun manfaat dari teknik akrostik ialah sebagai berikut: 1) Mengarahkan siswa dalam menemukan ide dari sesuatu yang dikenal dan berada di sekitarnya, 2) Membantu siswa dalam memperkaya perbendaharaan kosakata, 3) Membantu siswa menemukan kata pertama dalam puisinya, 4) Membimbing siswa melakukan tahap-tahap menulis puisi, 5) Dapat membantu siswa mengingat informasi lebih cepat dan mempertahankan lebih lama.

Bertitik tolak pada teori tersebut, maka guru dapat mengkombinasikan beberapa model pembelajaran dengan teknik akrostik agar pembelajaran puisi menggunakan teknik akrostik dapat meningkatkan keterampilan siswa-siswi untuk memperbanyak pembendaharaan kata, mengasah keindahan dalam merangkai kata pada sebuah bait, dan mengetahui makna yang akan disampaikan pada pembacanya. Serta agar pembelajaran dapat terlihat menarik untuk diikuti oleh siswa. Urgensi pada penelitian yang dibuat ialah dengan menerapkannya teknik akrostik pada pembelajaran menulis puisi, maka siswa dapat menggali daya imaji dan keterampilannya dalam membuat sebuah diksi yang bebas dalam menulis puisi pada tema cita-citaku.

Tujuan dari penelitian ini ialah untuk mengetahui keterampilan menulis puisi siswa kelas IV MI Negeri Margasari (MIN 02 Kota Bandung) sebelum diterapkannya Teknik Akrostik, kemudian untuk mengetahui proses penerapan Teknik Akrostik pada keterampilan menulis puisi siswa, dan untuk mengetahui peningkatan keterampilan menulis puisi siswa setelah diterapkan teknik Akrostik pada setiap siklus. Manfaat teroritis pada penelitian ini 
dapat bermanfaat bagi khasanah pendidikan dalam pengembangan teknik pembelajaran serta dapat menjadi landasan dalam melaksanakan proses pembelajaran, meningkatkan kualitas keterampilan menulis siswa lewat puisi pada pembelajaran tematik di sekolah, dan mengajak siswa agar berani menuangkan ide dalam bentuk bahasa tulis. Selain itu manfaat dari penelitian ini dapat dirasakan bagi guru, siswa, dan sekolah MIN Margasari.

\section{METODOLOGI}

Metode penelitian ini menggunakan Penelitian Tindakan Kelas (PTK), metode ini berorientasi pada penerapan tindakan dengan tujuan peningkatan mutu atau pemecahan masalah pada suatu kelompok subjek yang diteliti, serta mengamati tingkat keberhasilan atau akibat dari tindakan tersebut (Salahudin, 2015). Pelaksanaan penelitian ini melalui II siklus dan pada setiap siklusnya terdiri dari perencanaan, pelakasanaan, pengamatan, dan refleksi. Penelitian Tindakan Kelas (PTK) dilaksanakan dalam bentuk praktik pembelajaran di dalam kelas dengan upaya memperbaiki dan mneingkatkan kualitas proses belajar dan melatih keterampilan yang dimiliki siswa dalam menulis puisi dengan melakukan tindakan secara kolaboratif dan sistematis melalui perencanaan, tindakan observasi, dan refleksi. Penelitian ini dilaksanakan pada bulan Maret-April 2018 di MIN Margasari Kelurahan Derwati Kecamatan Rancasari Kota Bandung, Jawa Barat pada semester II tahun ajaran 2017/2018. Dengan jumlah siswa kelas IV B sebanyak 28 orang yang terdiri dari 15 laki-laki dan 13 perempuan. Jenis data yang digunakan pada penelitian ini adalah kuantitatif dan kualitatif. Data kuantitatif ialah data yang berupa angka atau yang dikuantitatifkan dalam paparnnya (Musfiqon, 2012, hal. 151). Data kuantitatif yang digunakan pada penelitian ini adalah pretest dan posttest dalam bentuk uraian yang harus diisi oleh siswa dalam pembelajaran Bahasa Indonesia dengan menggunakan Teknik Akrostik untuk mengetahui keterampilan siswa dalam menulis puisi. Teknik pengumpulan data dilakukan dengan tes, observasi, wawancara, dan studi dokumentasi. Teknik pengumpulan data dilakukan dengan tes, observasi, wawancara, dan studi dokumentasi.

Teknik analisis data obervasi dapat dilihat dari jumlah persentase rata-rata aktivitas belajar siswa. Hasil observasi dapat dihitung dengan menjumlahkan skor aktivitas yang tercapai oleh siswa dan kemudian di bagi rata-ratanya. Adapun hitungan presentase penilaian aktivitas siswa dan guru yang dilakukan dengan menggunakan rumus berikut:

rata-rata aktivitas guru dan siswa $=\frac{\text { Jumlah aktivitas yang tercapai }}{\text { Seluruh } \text { Aktivitas }} \boldsymbol{x} \mathbf{1 0 0}$

Adapun hasil presentase yang diperoleh ke dalam kriteria keterlaksanaan apat diuraikan dalam tabel sebagai berikut:

Tabel 1. Presentase Aktivitas

\begin{tabular}{|c|c|c|}
\hline $\begin{array}{c}\text { Persentase } \\
(\%)\end{array}$ & Bobot & Kualifikasi \\
\hline $86-100$ & 4 & Sangat baik \\
\hline $76-85$ & 3 & Baik \\
\hline $60-75$ & 2 & Sedang \\
\hline $55-59$ & 1 & Kurang \\
\hline$\leq 54$ & 0 & Sangat Kurang \\
\hline \multicolumn{3}{|c}{ (Purwanto, 2012) } \\
\hline
\end{tabular}

Sedangkan pengolahan data tes dilihat dari hasil penilaian unjuk kerja terhadap hasil tulisan puisi yang dibuat oleh siswa selama proses pembelajaran Bahasa Indonesia menggunakan Teknik Akrostik. Pada penelitian ini peneliti memberikan rentang skor 1-4, dengan perhitungan skor maksimal 16. Penilaian ini bertujuan untuk mnegukur keterampilan 
menulis puisi pada siswa. Untuk mengetahui peningkatan keterampilan menulis puisi siswa pada setiap tindakannya digunakan rumus sebagai berikut:

Ketercapaian Individu $=\frac{\text { Jumlah skor diperoleh }}{\text { Jumlah skor maksimal }} \times 100$

Tinggi rendahnya skor unjuk kerja yang diperoleh siswa, dapat diukur dengan meggunakan skala rentang sebagai berikut:

Tabel 2. Skoring Rubrik Penilaian

\begin{tabular}{|c|l|c|c|c|c|}
\hline \multirow{2}{*}{ No } & \multicolumn{2}{|c|}{ Aspek penilaian } & \multicolumn{4}{c|}{ Skala penliaian } \\
\cline { 3 - 6 } & & 1 & 2 & 3 & 4 \\
\hline 1 & Tema & & & & \\
\hline 2 & Gaya Bahasa (Majas) & & & & \\
\hline 3 & Kosa kata (Diksi) & & & & \\
\hline 4 & Rima & \multicolumn{5}{|c|}{16} \\
\hline & Jumlah & \multicolumn{5}{|c|}{} \\
\hline & Skor Maksimal &
\end{tabular}

Sumber: (Abidin, Pembelajaran Bahasa Berasis Pendidikan Karakter, 2013)

Tabel 3. Kriteria Tes Keterampilan Menulis Puisi

\begin{tabular}{|c|c|c|c|}
\hline $\mathrm{No}$ & Indikator & Kriteria & Skor \\
\hline 1. & $\begin{array}{c}\text { Diksi } \\
\text { (pilihan kata) }\end{array}$ & $\begin{array}{l}\text { a. Pilihan kata tepat dan jelas } \\
\text { b. Pilihan kata cukup baik } \\
\text { c. Pilihan kata cukup baik tetapi monoton } \\
\text { d. Pilihan kata tidak tepat }\end{array}$ & $\begin{array}{l}4 \\
3 \\
2 \\
1\end{array}$ \\
\hline 2. & $\begin{array}{c}\text { Majas } \\
\text { (Gaya Bahasa) }\end{array}$ & $\begin{array}{l}\text { a. Menggunakan gaya bahasa majas } \\
\text { b. Menggunakan sedikit gaya bahasa majas } \\
\text { c. Kurang menggunakan gaya bahasa majas } \\
\text { d. Tidak menggunakan gaya bahasa majas }\end{array}$ & $\begin{array}{l}4 \\
3 \\
2 \\
1\end{array}$ \\
\hline 3. & Tema & $\begin{array}{l}\text { a. Tema sesuai dengan judul dan isi puisi } \\
\text { b. Tema sesuai dengan judul puisi tetapi tidak } \\
\text { sesuai dengan isi puisi } \\
\text { c. Tema kurang sesuai dengan isi puisi } \\
\text { d. Tema tidak sesuai dengan isi puisi }\end{array}$ & $\begin{array}{l}4 \\
3 \\
2 \\
1\end{array}$ \\
\hline 4. & Rima & $\begin{array}{l}\text { a. Rima yang digunakan bervariasi } \\
\text { b. Rima yang digunakan cukup bervariasi dan } \\
\text { menambah estetika puisi } \\
\text { c. Rima kurang memperkuat ekspresi puisi dan } \\
\text { kurang menambah estetika puisi } \\
\text { d. Rima tidak bervariasi dan tidak memiliki } \\
\text { estetika puisi }\end{array}$ & 3 \\
\hline
\end{tabular}

Sumber : (Abidin, Pembelajaran Bahasa Berasis Pendidikan Karakter, 2013)

Setelah dilakukan perhitungan unjuk kerja pada hasil menulis puisi yang diperoleh siswa, selanjutnya menentukan rata-rata dengan menggunakan rumus:

nilai rata-rata yang diperoleh siswa $=\bar{x}=\frac{\sum X}{N}$ 
Keterangan :

$\bar{x}=$ Rata-rata

$\sum X=$ Jumlah Seluruh Skor

$\mathrm{N}$ = Banyak Subjek (Sudjana, 2009)

Untuk menghitung ketuntasan nilai klasikal, jika kurang dari $85 \%$ proses pembelajaran perlu perbaikkan, tentu tidak dianjurkan untuk melanjutkan pada pembelajaran berikutnya. Sedangkan jika melebihi dari $85 \%$ dapat melanjutkan pada program pemelajaran berikutnya (Hayati, 2013, hal. 152). perhitungan tersebut dapat menggunakan rumus sebagai berikut:

Ketuntasan nilai klasikal $=\frac{\text { jumlah siswa yang memperoleh nilai } \geq 75}{\text { jumlah seluruh siswa }} \times 100 \%$

\section{HASIL DISKUSI}

a. Hasil belajar siswa pada Pra siklus

Penelitian ini diawali dengan kegiatan pra siklus dengan tujuan untuk mengetahui kondisi awal objek yang diteliti. Pembelajaran Bahasa Indonesia dengan materi puisi pada tema cita-citaku sub tema aku dan cita-citaku dengan menggunakan metode konvensional dalam proeses pembelajarannya. Pada proses pemberian materi mengenai puisi masih banyak siswa yang belum begitu paham dengan materi puisi dan apa yang dimaksud dengan karya tulis puisi. Di akhir pembelajaran, guru menyimpulkan materi yang dibahasnya. Kondisi yang terjadi ketika pembelajaran berlangsung ialah, siswa cenderung hanya mendengarkan tanpa memahami materi yang disampaikan. Ketika praktek menulis materi puisi siswa diminta untuk menulis puisi dengan tema "cita-citaku" saat akan memulai untuk menulis puisi siswa cenderung terlihat bingung saat akan merangkai sebuah kata pada larik yang mereka buat, selain itu siswa juga terlihat kesulitan saat harus memadupadankan bunyi pada akhir kata disetiap akhir bait puisinya. Selain itu ada pula siswa yang tidak mau menulis puisi karena tidak mengerti pola pada penulisan puisi yang harus ia buat. Tak jarang, ada beberapa siswa yang malah menjiplak pada tulisan yang terdapat pada buku tulis. Gejalagejala tersebut dapat diatasi apabila guru menggunakan teknik pembelajaran yang tepat keterampilan menulis siswa dalam pembelajaran sastra lainnya yang membutuhkan menulis untuk penyampaiannya. Sehingga dampak yang terjadi ialah plagiarisme pada hasil karya puisi siswa yang yang mereka salin dari buku paket, ataupun membuat puisi tanpa memahami maknanya. Sebelum diterapkannya pembelajaran teknik akrostik, hasil penilaian keterampilan menulis puisi siswa menunjukkan nilai rata-rata sebesar 46,87 dengan keterangan perlu perbaikan. Berdasarkan kegiatan awal pra siklus, dapat disimpulkan bahwa hanya 4 siswa yang dapat memenuhi syarat nilai KKM, sedangkan sisanya sebanyak 24 siswa masih masuk pada kategori sangat kurang. Oleh karena itu, untuk meningkatkan keterampilan menulis puisi siswa pada mata pelajaran Bahasa Indonesia maka peneliti menerapkan pembelajaran teknik akrostik untuk mengatasi permasalahan tersebut.

\section{b. Aktivitas Guru dan Siswa Pada Siklus I}

Aktivitas guru siklus I menunjukkan bahwa aktivitas guru selama pembelajaran menggunakan teknik akrostik termasuk pada kriteria sedang, dengan perolehan nilai persentase rata-rata sebesar $64,15 \%$ dengan kategori sedang dan indikator yang belum tercapai sebesar 38,85\%. Sedangkan aktivitas siswa pada siklus I selama mengikuti kegiatan pembelajaran memperoleh nilai persentase rata-rata sebesar $61,65 \%$ dengan kategori sedang, dan indikator yang belum tercapai sebesar 38,35\%. Aspek ketercapaian yang belum maksimal pada siklus I dikarenakan masih kurangnya aktivitas belajar siswa dengan 
menggunakan teknik akrostik yang diterapkan oleh guru, karena penataan proses pembelajaran masih disesuaikan sehingga siswa merasa asing dengan teknik pembelajaran tersebut. Oleh karena itu, aktivitas guru dan siswa masih harus ditingkatkan pada siklus II agar seluruh tahapan dapat tersampaikan secara keseluruhan.

Adapun persentase aktivitas guru pada siklus Ijika dibuat dalam bentuk diagram, maka seperti terlihat pada gambar 1 sebagai berikut:

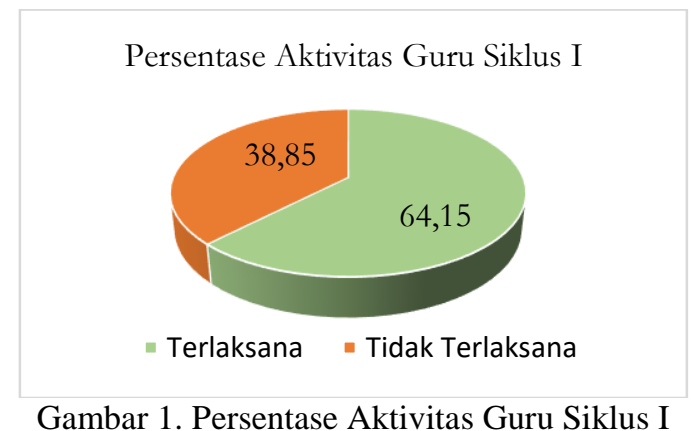

Berdasarkan hasil persentase tersebut, maka tigkat keterlaksanaan aktivitas guru pada siklus I adalah $64,15 \%$ dengan kategori sedang.

Sedangkan persentase aktivitas siswa pada siklus I jika dibuat dalam bentuk diagram, maka seperti terlihat pada gambar 2 sebagai berikut:

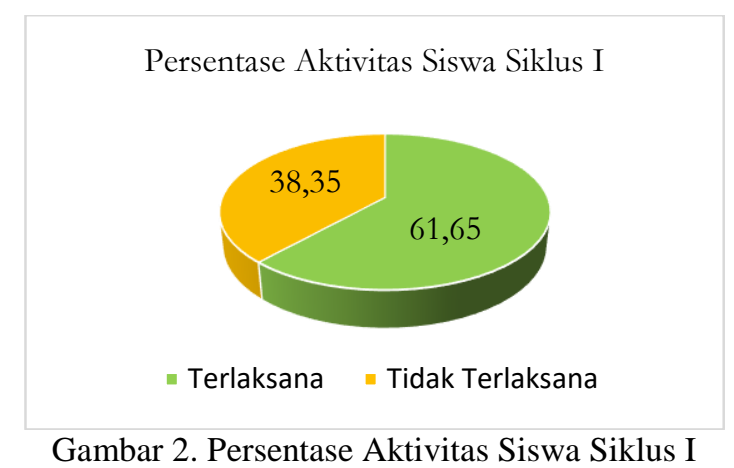

Berdasarkan gambar 2 dapat dilihat bahwa aktivitas belajar siswa pada siklus I mencapai $61,65 \%$ yaitu termasuk ke dalam kategori sedang.

\section{c. Aktivitas Guru dan Siswa Pada Siklus II}

Aktivitas guru yang dilaksanakan pada siklus II memproleh peningkatan dengan nilai persentase sebesar $89,1 \%$ dengan kategori sangat baik. Hal ini menunjukkan bahwa ketercapaian aktivitas guru pada siklus II sudah mencapai secara keseluruhan. Sedangkan aktivitas belajar siswa selama mengikuti pembelajaran pada siklus II memperoleh nilai persentase sebesar $87,5 \%$ dengan kategori sangat baik.

Adapun persentase aktivitas guru pada siklus II jika dibuat dalam bentuk diagram, maka seperti terlihat pada gambar 3 sebagai berikut: 


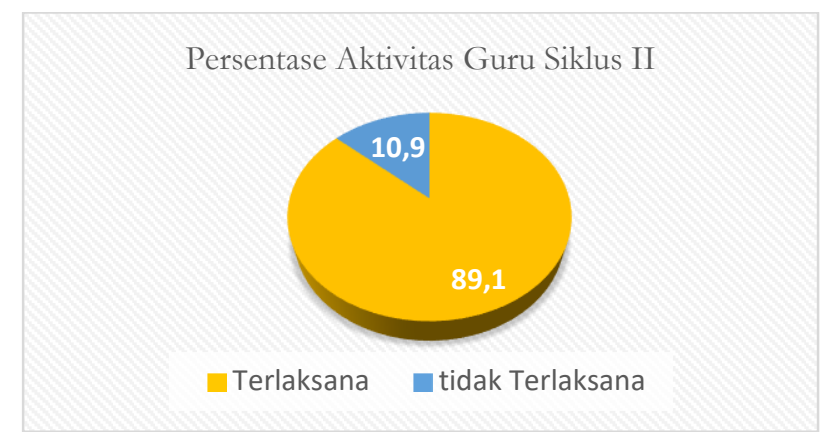

Gambar 3. Persentase Aktivitas Guru Siklus II

Berdasarkan gambar 3 dapat dilihat bahwa aktivitas mengajar guru pada siklus II mencapai $89,1 \%$ yaitu termasuk ke dalam kategori sangat baik.

Sedangkan persentase aktivitas siswa pada siklus II jika dibuat dalam bentuk diagram, maka seperti terlihat pada gambar 4 sebagai berikut:

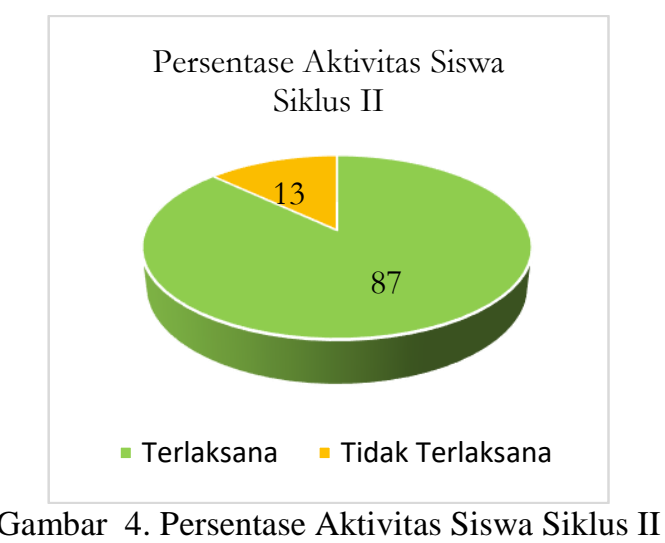

Berdasarkan gambar 4 dapat dilihat bahwa aktivitas belajar siswa pada siklus II mencapai $87 \%$ yaitu termasuk ke dalam kategori sangat baik.

d. Keterampilan Menulis Puisi Siswa Menggunakan Teknik Akrostik Pada Setiap Siklus

Setelah diterapkannya teknik akrostik pada siklus I tindakan 1 nilai rata-rata keterampilan menulis puisi yang diperoleh siswa mengalami peningkatan menjadi 63,3 dan perolehan nilai ketuntasan belajar siswa sebesar 32,1\%, dengan kriteria belum tuntas. Persentase ketuntasan belajar siswa dapat dilihat pada tabel berikut:

Tabel 4. Persentase Ketuntasan Belajar Siswa Siklus I Tindakan 1

\begin{tabular}{|c|c|c|}
\hline Nilai KKM Sekolah & Unjuk Kerja Siswa & Jumlah Siswa \\
\hline \multirow{2}{*}{75} & $\leq 75$ & 19 siswa \\
\cline { 2 - 3 } & $\geq 75$ & 9 siswa \\
\hline
\end{tabular}

Dari jumlah 28 siswa dapat disimpulkan bahwa 19 siswa dengan kategori sangat kurang, sedangkan sisanya sebanyak 9 siswa memiliki keterampilan menulis dengan kategori sedang. Pada siklus I tindakan 2 nilai rata-rata keterampilan menulis puisi yang diperoleh siswa mengalami peningkatan menjadi 75,6 dan perolehan nilai ketuntasan belajar siswa sebesar $71,4 \%$, dengan kriteria belum tuntas. Persentase ketuntasan belajar siswa dapat dilihat pada tabel berikut: 
Tabel 5. Persentase Ketuntasan Belajar Siswa Siklus I Tindakan 2

\begin{tabular}{|c|c|c|}
\hline Nilai KKM Sekolah & Unjuk Kerja Siswa & Jumlah Siswa \\
\hline \multirow{2}{*}{75} & $\leq 75$ & 8 siswa \\
\cline { 2 - 3 } & $\geq 75$ & 20 siswa \\
\hline
\end{tabular}

Dari jumlah 28 siswa dapat disimpulkan bahwa 8 orang siswa yang tuntas sementara 20 orang siswa lainnya berada di kategori belum tuntas. Berdasarkan hasil tes menulis puisi pada tindakan 1 dan tindakan 2 Perolehan nilai hasil tes menulis puisi siswa siklus I sebesar 69,45 dengan kategori sedang, dan diperoleh hasil nilai klasikal menulis puisi dengan menggunakan teknik akrostik pada siklus I sebanyak 51,75\% dengan sangat kurang. Adapun peningkatan pada nilai keterampilan menulis puisi siswa secara individu pada tindakan 1 dan 2 dapat dilihat pada grafik berikut:

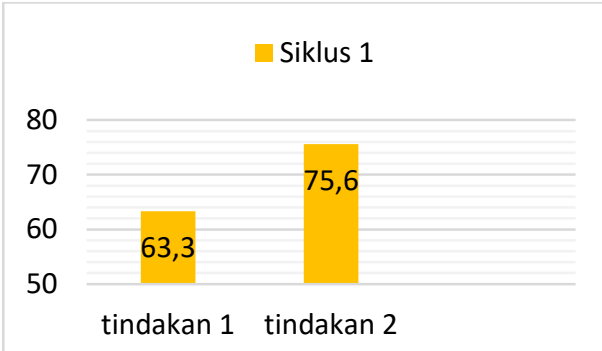

Gambar 5. Peningkatan Nilai Tes Menulis Puisi Siklus I

Dengan demikian, berdasarkan data yang telah diuraikan pada siklus I, perlu adanya perbaikan mutu pembelajaran pada siklus berikutnya agar keterampilan menulis puisi siswa mengalami peningkatan.

Peneliti melanjutkan penelitian pada siklus II dengan memperbaiki kekurangan pada siklus I dengan harapan memperoleh hasil yang optimal. Setelah diterapkannya teknik akrostik pada siklus II tindakan 1 diperoleh peningkatan nilai hasil keterampilan menulis puisi yang menunjukkan nilai rata-rata siswa sebesar 85 dan perolehan nilai persentase ketuntasan belajar klasikal sebesar $82,14 \%$ dengan keterangan pembelajaran perlu perbaikkan. Persentase ketuntasan belajar siswa dapat dilihat pada tabel berikut:

Tabel 6. Persentase Ketuntasan Belajar Siswa Siklus II Tindakan 1

\begin{tabular}{|c|c|c|}
\hline Nilai KKM Sekolah & Unjuk Kerja Siswa & Jumlah Siswa \\
\hline \multirow{2}{*}{75} & $\leq 75$ & 22 siswa \\
\cline { 2 - 3 } & $\geq 75$ & 6 siswa \\
\hline
\end{tabular}

Dari jumlah 28 siswa dapat disimpulkan bahwa 6 orang siswa masih belum tuntas sementara 22 orang siswa lainnya berada di kategori tinggi. Pada siklus II tindakan 2 diperoleh peningkatan nilai hasil keterampilan menulis puisi yang menunjukkan nilai ratarata siswa sebesar 93,75 dan perolehan nilai persentase ketuntasan belajar klasikal sebesar $100 \%$.

Tabel 7. Persentase Ketuntasan Belajar Siswa Siklus II Tindakan 2

\begin{tabular}{|c|c|c|}
\hline Nilai KKM Sekolah & Unjuk Kerja Siswa & Jumlah Siswa \\
\hline \multirow{2}{*}{75} & $\leq 75$ & 28 siswa \\
\cline { 2 - 3 } & $\geq 75$ & 0 siswa \\
\hline
\end{tabular}

Hal ini menunjukkan bahwa, tidak adanya siswa yang memiliki keterampilan menulis puisi yang sangat kurang. Semua siswa mengalami peningkatan keterampilan menulis puisinya. Adapun peningkatan keterampilan menulis puisi siswa pada tindakan 1 dan 2 dapat dilihat pada grafik berikut: 


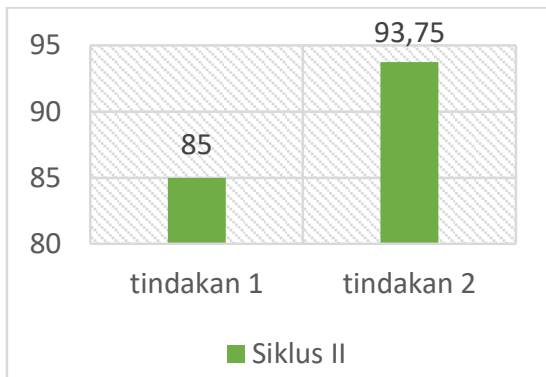

Gambar 6. Persentase Nilai Tes Menulis Puisi Siklus II

Dengan demikian, hipotesis tindakan yang diajukan peneliti terjawab dengan simpulan akhir bahwa penerapan teknik akrostik untuk meningkatkan keterampilan menulis puisi pada tema cita-citaku sub tema aku dan cita-citaku dalam mata pelajaran Bahasa Indonesia di kelas IV B MIN Margasari (MIN 02 Kota Bandung). Berdasarkan hasil tes menulis puisi pada tindakan 1 dan tindakan 2 Perolehan nilai hasil tes menulis puisi siswa siklus II sebesar 89,37dengan kategori sedang, dan diperoleh hasil nilai klasikal keterampilan menulis puisi dengan menggunakan teknik akrostik pada siklus II sebanyak 91\% dengan kategori sangat baik. Berdasarkan kriteria ketuntasan belajar, bahwa sebuah kelas dinyatakan telah tuntas belajar jika jumlah siswa kelas telah mencapai ketuntasan belajar $85 \%$.

Adapun peningkatan keterampilan menulis puisi siswa pada pra siklus, siklus I, dan siklus II dapat dilihat pada grafik berikut:

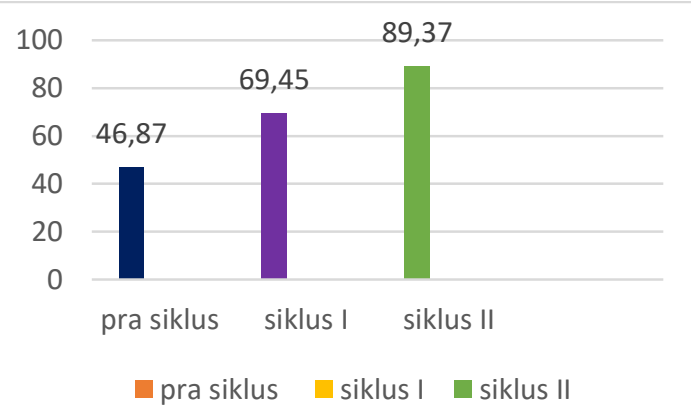

Gambar 7. Peningkatan Keterampilan Menulis Puisi Siswa di Setiap Siklus

\section{KESIMPULAN}

Keterampilan komunikasi siswa kelas IV B MIN Margasari (MIN 02 Kota Bandung) pada mata pelajaran Bahasa Indonesia tema cita-citaku sub tema aku dan cita-citaku menggunakan teknik akrostik menjadi meningkat. Hal ini ditunjukkan dengan diperolehnya nilai rata-rata 46,87 dengan kategori sangat kurang dan persentase ketuntasan belajar sebesar 14\% dengan kategori sangat kurang berdasarkan nilai KKM yang ditentukan oleh sekolah yaitu 75. Hal tersebut dikarenakan teknik pembelajaran yang monoton sehingga siswa kurang berkontribusi dalam mengikuti pembelajaran yang mengakibatkan kurangnya siswa dalam mengasah keterampilan menulis puisi. Keterampilan menulis puisi siswa dengan menggunakan teknik akrostik telah mengamati peningkatan pada setiap siklusnya. Pada siklus I, hasil penilaian keterampilan menulis puisi siswa memperoleh nilai rata-rata sebesar 69,45 dengan kategori sedang, dan diperoleh hasil nilai klasikal keterampilan menulis puisi dengan menggunakan teknik akrostik pada siklus I sebanyak 51,75\% . Kemudian pada siklus II mengalami peningkatan dengan niali rata-rata sebesar 89,37dengan kategori sedang, dan diperoleh hasil nilai klasikal keterampilan menulis puisi dengan menggunakan teknik akrostik pada siklus II sebanyak $91 \%$ dengan kategori sangat baik. 


\section{DAFTAR PUSTAKA}

Abidin, Y. (2013). Pembelajaran Bahasa Berasis Pendidikan Karakter. Bandung: PT Radika Aditama.

Aisyiyah, I. d. (2013). Landasan Pendidikan. Bandung: Alfabeta.

Dadang, I. d. (2014). Strategi Pembelajaran Bahasa. Bandung: Rosda.

Hayati, T. (2013). Evaluasi Pembelajaran. Bandung: CV Insan Mandiri.

Kadir, A. d. (2014). Pembelajaran Tematik. Jakarta: PT Raja Grafindo Persada.

Magee, W. (2008). Asyiknya Menulis Puisi Wujudkan ide-ide cemerlangmu. Solo: Tiga Serangkai.

Musfiqon. (2012). Metodologi Penelitian Pendidikan. Jakarta: Prestasi Pustaka Publisher.

Nur, D. (2010). Pengertian, Pelaksanaan, dan Manfaat Teknik Akrostik. http://dewinur.blogspot.co.id/2010/12/pengertian-pelaksanaan-dan-manfaat.html, 5.

Purwanto, N. ( 2012). Prinsip-prinsip Evaluasi Pengajaran. Bandung: PT. Remaja Rosdakarya.

Rukiati K., E. (2014). Pembelajaran Bahasa Indonesia kajian Psikologi, teori dan Metodologi Pembelajaran. Bandung: CV. Insani Mandiri.

Salahudin, A. (2015). Penelitian Tindakan Kelas . Bandung: PT Pustaka Setia.

Salam. (2009). Menulis Puisi dengan Teknik Akrostik. http://pelitapendidikan.blogspot.com/2009/pembelajaran-menulis-puisidengan.html, 2.

Sudjana, N. (2009). Penilaian Hasil Proses Belajar Mengajar. Bandung: PT. Remaja Rosdakarya.

Suhendar, I. d. (2008). Strategi Pembelajaran Bahasa. Bandung: PT Remaja Rosdakarya.

Taoziri, A. (2013). Penggunaan Teknik Akrostik Dalam meningkatkan Kemampuan Menulis Puisi Bebas Kelas VIII C SMP Pasundan 4. Bandung. Tidak Diterbitkan. http://ejournal.upi.edu/index.php/PSPBSI/article/download/413/292, 3 